\title{
A CASE STUDY OF PROFESSIONALIZATION AND SUCCESSION IN A FAMILY BUSINESS
}

\author{
${ }^{* 1}$ Nathan Peixoto Oliveira, ${ }^{2}$ Luciane Ferreira Lopes Santos \\ ${ }^{1,2}$ Université de Bordeaux, 33000, Bordéus-AQ, França \\ nathanpeixot@yahoo.com.br
}

\begin{abstract}
By recognizing the contribution of the family company in the economy of different countries, there was an interest in evaluating how these organizations, very often linked to the entrepreneurship spirit of a person or family, can give continuity, longevity and impress success in its trajectory. The complexity of the market requires adaptability and efficiency; thus, professionalization and succession are important problems to be solved. To understand this subject in a practical environment, a case study was carried out, analyzed by the literature review lens. A family company was chosen, working in the cleaning and conservation segment in Rio de Janeiro - Brazil and the results revealed that the success of professionalization, as well as the succession process, requires people with appropriate skills and competencies to conduct the processes in a structured way. In addition, if there is no previous planning and change management in family companies, the chances of success are smaller, more difficult to implement and may even compromise the future of the organization.
\end{abstract}

Keywords: Family Business; Professionalization; Succession.

\section{UM ESTUDO DE CASO DE PROFISSIONALIZAÇÃO E SUCESSÃO EM UMA EMPRESA FAMILIAR}

\section{RESUMO}

Ao reconhecer a contribuição da empresa familiar na economia de diferentes países, houve um interesse em avaliar como essas organizações, muitas vezes ligadas ao espírito empreendedor de uma pessoa ou família, podem dar continuidade, longevidade e imprimir sucesso em sua trajetória. A complexidade do mercado exige adaptabilidade e eficiência; assim, a profissionalização e a sucessão são problemas importantes a serem resolvidos. Para compreender este assunto em um ambiente prático, foi realizado um estudo de caso, analisado à luz da revisão da literatura. Uma empresa familiar foi escolhida, atuando no segmento de limpeza e conservação no Rio de Janeiro - Brasil, e os resultados revelaram que o sucesso da profissionalização, bem como o processo de sucessão, requer pessoas com habilidades e competências adequadas para conduzir os processos de forma estruturada. E caso não haja planejamento prévio e gerenciamento de mudanças nas empresas familiares, as chances de sucesso são menores, mais difíceis de implementar e podem até comprometer o futuro da organização.

Palavras-chave: Empresa Familiar; Profissionalização; Sucessão. 


\section{Como Citar:}

OLIVEIRA, Nathan Peixoto; SANTOS, Luciane Ferreira Lopes. A CASE STUDY Of PROFESSIONALIZATION AND SUCCESSION IN A FAMILY BUSINESS. In: SIMPÓSIO DE PESQUISA OPERACIONAL E LOGÍSTICA DA MARINHA, 19., 2019, Rio de Janeiro, RJ. Anais [...]. Rio de Janeiro: Centro de Análises de Sistemas Navais, 2019. 


\section{INTRODUCTION}

\subsection{Theme Presentation}

After the opening of the market, the advent of globalization, and the current reality of the Brazilian economy, has strongly impacted the country's companies, promoting deep changes in its business, whether in strategy, management model, partnerships, geographical area, price or portfolio services. Households do not pass unharmed in this environment of profound changes. In a highly competitive environment, those that adapt faster, respond with resilience, innovate and control their costs more efficiently will survive.

According to the Brazilian Micro and Small Business Support Service (SEBRAE, 2016), micro and small enterprises account for about $98 \%$ of Brazilian companies, representing 5 million establishments and $56 \%$ of legal jobs. A significant part of these companies is family owned, approximately $90 \%$ of the companies in the country are familiar. With such a diverse profile: from bakery or dyeing, to large corporations - such as the Votorantin and Pão de Açúcar groups, Klabin, among others, together, account for 2 million direct jobs in Brazil. Another good news is the participation of these companies in the Product Gross Domestic Product (GDP): $12 \%$ of the agribusiness segment, 34\% of industry and 54\% of services.

Given this data, it becomes relevant all work that promotes greater knowledge of the family business. From the economic and social development of the country, through recognition of the source of employment and income, to reach the living space and reproduction of Brazilian culture, the family business has great lessons to offer. In the universe of the family business besides the concerns related to the economy, politics, competition, consumer etc., it is also necessary to prepare for the moment of succession. According to Oliveira (2010, p.11), "the succession process represents one of the most important moments for optimizing the continuity of the family business".

According to Lodi (1998), conflicts arising at the time of succession are the result of structural problems of families rooted years ago. Bernhoeft and Gallo (2003) can be understood as a transference of power, capital, leadership between the current ruling generation and the future generation that will take over, a complex moment that profoundly affects the familiar and unfamiliar environment.

Regarding success in the process of succession, the literature presents some causes, one of which is the absence of succession planning, lack of training, knowledge, professionalization and discipline in the accomplishment of the planned actions. Conflict of interest among family members often appears as a relevant factor that can put the process of succession

The concept of family business is not unanimous among the authors that will be presented in this paper, but the perspective of each one was considered when delimited family business where control is centralized in one or more families and that its business control goes to the next generations based on heredity.

\subsection{OBJeCtives}

For Lodi (1998), some of the factors that negatively influence the family management: absence or low professionalization of the company, family interests overlapping the interests of the firm and the resistance of the founders and members in the succession process and organizational professionalization.

Having these elements given the present work aims to study how the process of professionalization and succession in a specific family business takes place as a case study. A 
secondary objective was to present the concept, the history and life cycle of this family business placed in Brazil.

\subsection{JUSTIFICATION}

Unsurprisingly, family businesses represent the vast majority of organizations in Brazil and Europe and are responsible for considerable employability. Thus, the solution of the problems presented by these companies is also important for the development of these countries. According to Oliveira (2010) family businesses in the United States represent about $55 \%$ of GDP and represent $40 \%$ of the country's business income. However, even with such relevance, approximately $40 \%$ of these companies do not continue after the first year of life and $70 \%$ of companies are closed when their founder dies.

According to Oliveira (2010), the average life cycle of non-family companies in the United States is 45 years, and that of family businesses is 24 years. In Brazilian reality, the author shows that the average life cycle of non-family businesses is 12 years, and that of family businesses is nine years. Only $30 \%$ of family businesses move to the second generation and no more than $5 \%$ have reached the third generation.

As the succession process is inevitable and critical for companies, deepening this theme in the reality of family companies is contributory to support them in conducting the process increasing their chances of continuity.

\subsection{Methodology}

To understand the professionalization and succession process was a made a

descriptive and qualitative case study out in a family company with 23 years in the cleaning services market in the city of Rio de Janeiro, Brazil. The group studied will have its identity preserved being named Company X. Company $\mathrm{X}$ was in the process of succession from the first to the second generation when it faced a severe crisis and was forced to sell the company to another family group. This family group is responsible for Segur SP, a company specializing in asset security and is also conducting its succession process. The professionalization of Company $\mathrm{X}$, the conduction of its succession process will be the objects of research in this present work.

The choice of a single company was due to the availability of access to information. The author of this study worked during two years in the organization being able to realize participant observation, unstructured interviews, and analysis of internal documents. About 400 hours of work were spent, reading and analyzing 346 corporate reports, participation in 40 management meetings related to strategic planning. Also, the five company directors, ten managers (two from each board), former employees were interviewed.

\section{THEORETICAL FOUNDATION}

\subsection{FAMILY BUSINESS}

Analyzing the universe of the family business arouses the interests of several national and international scholars. Gersick, Davis, Hampton and Lansberg (2006) presents the 1960s and 1970s as the first period in which this theme began to be considered more relevant. Martins, Menezes and Bernhoeft (2012) show that studies on family-owned businesses have become more consistent with the emergence of the Family Business Review in 1968, an American magazine dedicated to discussing and exposing the subject. In Brazil, studies on family firms are more recent, dating to their representative appearance in the early 1990s, according to Cançado et al. (2011).

For Borges and Lescura (2012) the interest in studying this type of organization rests on the challenges and peculiarities they face, being: the family-company relationship; 
conflicts of a family and generational nature; the different demands for levels of professionalization and administrative structuring of activities; market competitiveness and continuity in business and the process of succession.

Different authors sought to define the concept of family business, but there is still no consensus. In this way, the description of the point of view of several authors and the concept that will be used to conduct the present study will be presented bellow. Burgens and Rogers apud Elsen (2002) conceptualizes the family as a unit of people in interaction, a semi-open system with a natural history composed of several stages, each of which corresponds to specific tasks on the part of the family. Lanzana and Constanzi (1999) present family organizations as actors that share the same value system, united by the same ideal, with administrative and financial control of the company. For Gonçalvez (2000), a family business can be conceptualized as the individuals that coexist two or more generations of the same family.

According to Gallo (2003), most of the concepts of family companies navigate around three aspects: ownership or control over the company; the power exercised by the family over the enterprise and the intention to transfer the company to future generations.

The difficulty of obtaining a closed concept regarding the family business according to Casillas, Vazquez and Díaz (2007) is a result of the focus of each author. Some focus more on content, others on presenting the differences between family and non-family business.

Adachi (2006) raised the different concepts available in the literature, noting that in the definition of family business there is no restriction regarding the area of activity of the company, its size, legal format of society or concerning the time of existence. According to the author, the crucial point that characterizes a family business is the influence that the family has in corporate and business control.

According to Ulrich (1997), a family is a company in which ownership and administration are in the hands of family members. Gaj (1990) states that family businesses are publicly or privately held in companies that have been started by a family member who has passed or will pass to an heir. Lodi (1998) complements saying that family businesses are those in which the consideration of succession of the board is linked to the hereditary factor and in which the institutional values identify with a family surname or the figure of the founder.

According to Leone (2005), a company is configured as a family if it has the following characteristics: initiated by a family member; family members participating in the property and direction; institutional values identified with a family surname or with the figure of the founder and succession tied to the hereditary factor.

Bernhoeft and Gallo (2003) present aspects that make the company of the family type, much more than the degree of kinship involved in a relationship between individual and organization. One can not understand a family business without first understanding family dynamics, just as one can not analyze family dynamics without first analyzing their relationship with their company (WERNER, 2004).

The interaction of these two inseparable aspects creates the necessary conditions for studying the whole of the family enterprise. This view also coincides with the definition given by Bernhoeft and Gallo (2003) that, regardless of whether the shareholding belongs to one or more families, the family business is characterized by reflecting in its culture the aspects that guide family relations.

Casillas et al. (2007) identifies as family business problems: the overlap between family and company; the difficulties to face growing internationalization; the difficulties to face an organizational renewal; the struggles to plan in advance the succession; the patrimony management and the governance inefficiency. Papa (2007) recognizes in the family business 
an organization conflicts due to the affective interweaving between the life history of the founders and family members with the company's history of conception.

\subsection{The Three Circles Model}

The Three Circles Model proposed by Gersick et al. (2006) originated from the works published in 1992 by Tagiuri and Davis. In these studies, the authors presented the need to differentiate the subsystems: ownership and management of the family business universe. When they looked at the distribution of individuals in family businesses, they noticed that not all family business owners participated in the company's management subsystem.

From this identification, Gersick et al. (2006) recognized the three circles as management, property, and family and also the groups that arise from the overlap of circles. To the total seven distinct sectors are created, and each of the company belongs to a sector, it follows the model presented in figure 1.

Figure 1: The three circles model

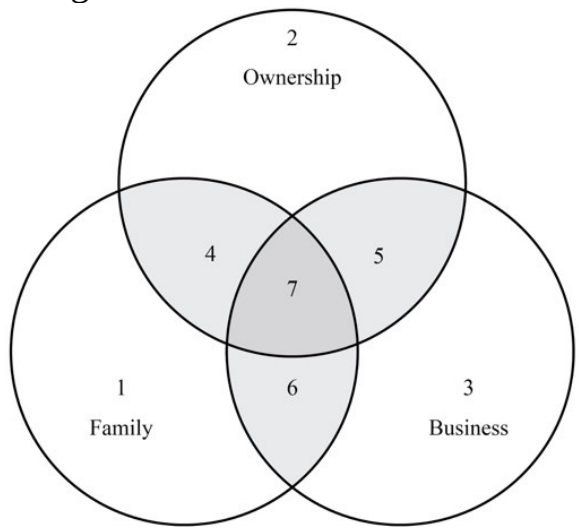

Source: Gersick et al. (2006, p.6)

1. Non-owner and non-manager families: all components of the family, direct descendants like those incorporated into the family share some interest or concern about the health and continuity of the company. The performance of these members and their influence will be more evident in the events and dynamics of interaction among the family, for example, lunches, weddings, baptisms, birthdays, death. There are always opportunities to address the family- business issue.

2. Non-family partners and non-managers: the corporate constitution of the first generation may have occurred in some ways. The figure of a single founder is not exclusive. In some situations, the company may have been born from the union of several families, as also the founder may have incorporated posteriori. This group has an exciting feature that are owners with no family ties. In some situations, depending on family conflicts, this team can act as a balance sheet.

3. Non-family and non-owner managers: this group can take various configurations. It is not always centered on a single founder. The first generation can start a business with multiple components from diverse backgrounds and family groups. Throughout the trajectory, there may be conflicts between the founder and the people who accompany him for years as a form of recognition and reward for loyalty.

4. Family owners who do not participate in the management: changeable over the generations, this means that interests are mutated with each new configuration of power pooling in the enterprise. This group has strong interests in the company. The heir can not act as "owner", and must articulate with the other owner's members.

5. Non-owner family managers: the most striking feature is the difficulty of differentiating the ownership of the company. The security they feel is supported much more by the family bond 


\section{SPOLM2O19}

XIX SIMPÓSIO DE PESQUISA OPERACIONAL E LOGISTICA DA MARINHA RIO DE JANEIRO, RJ, BRASIL - 06 A 08 DE NOVEMBRO DE 2019

than professional competence. Some businesses seek to nullify this individual's family involvement considering him only as an employee.

6. Managing partners who are not family members It is unnecessary to make a detailed exposition about this group because it stems from the combination of non-family owners and family members working in the company.

7. Family owners and managers In this group, people feel even more important and can make the mistake of confusing the roles of shareholders with their job responsibilities. In this group, issues such as the distinction of roles, participation in pay and salary politics, submission to the hierarchy, and salary policy are essential in helping these members not to confuse their roles.

Although the Three Circles Model is a tool that allows analyzing family businesses, it is a static observation. Thus, Time must be considered as a changing fator, so, studying the lifecycle and evolution over the years complements the analysis of the organization.

\subsection{FAMily BuSINESS LifeCyCLE}

The life cycle of the family business can be classified into three stages: (1) initial, beginning of business life, aimed at survival; the second step (2), focusing on expansion and structuring, a time for gradual growth; and the third stage (3), the stage of maturity, which has a slower growth characteristic. Figure 2 represents these stages.

Figure 2: Family business lifecycle

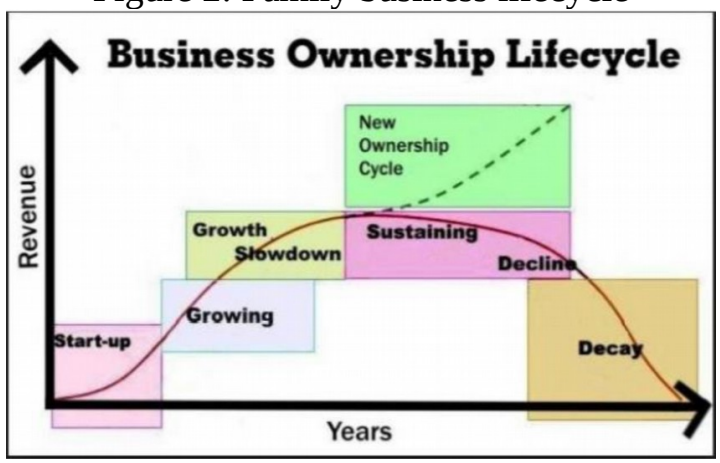

Source: Ceribeli, Merlo and Morais (2010, p. 237-238)

Based on Gersick et al. (2006), the change from one stage to another may be gradual or occur drastically. In the vast majority of family businesses, changes will occur in response to external events that induce change.

Following the analysis of Gersick et al. (2006) on the stages of the family business life cycle, the level of development of the company in the initial phase is characterized by being an informal structure and its owners acting centrally in all activities. Another characteristic of this stage is the predominance of a product or service, seeking to establish its long-term performance.

When the company is in the expansion stage its structure is more functional, its products or services are established in the market. In this phase, the significant challenge is the professionalization of the company, the strategic plan, policies and cash flow management.

In the maturity stage, the structure is more stable, has slow growth and established processes. Gersick et al. (2006) say that the challenges is to accept the new strategic focus, the commitment of managers, owners and the need for reinvestment. When companies reach this stage of maturity, they find it difficult to maintain a good performance.

For Davel, Silva and Fischer (2000), the family-oriented development process that is directed towards development follows in an orderly and sequential way. Gersick et al. (2006) propose that each subsystem of the Three Circles Model (property, family, and management) 
has its development, following its movements in different ways, thus generating different arrangements in companies.

Álvares (2003) analyzing the relationship between family, property, and management, recognizes four stages of family busines (figure 3):

1. Merged:the company has its systems heavily overlapped; Family members hold management positions. The capital is all familiar, and the equity of the company may be confused with that of the family; family's interests are confused or are more important than the company's; the owner orchestrates everything and makes all the decisions.

2. Undifferentiated: the presence of non-family professional administrators is substantial, but the interests and influence of the family over the organization are also substantial; the identity of the company is confused with that of the family.

3. Differentiated: the business and Family have their own identities: the Family may have shareholder control, but there is a separation between company's and family's interests. The objectives of the company are sovereign; shareholders understand that a successful business secures the family's long-term interests; the decision-making power is shared; the system opens.

4. Separate: there is the complete separation between family, company, and capital. In that case, it is no longer familiar. This feature is used to eliminate or reduce the problem, thus eliminating the family business figure, which only exists as a Separate Differentiated Undifferentiated Fusion linked to one or more families.

Figure 3: Degree of overlap of the family/property/company system
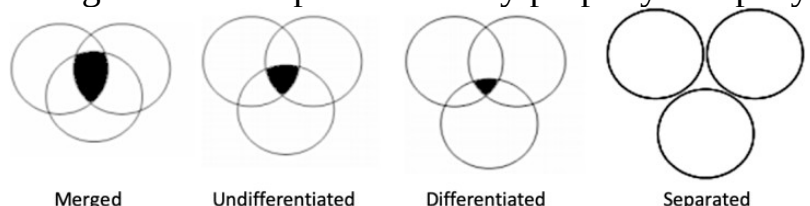

Source: Adapted from Álvares (2003)

\subsection{Family Business Professionalization}

Several authors present professionalization as one of the critical points for the continuity of family businesses. The process of administrative professionalization, according to Padula (2002), is the way in which the strategies of coordination of activities and the organizational efforts adopted by the administration are formalized as the company goes through the distinct phases of its growth. Professionalization is based on two main lines of action: the process of delegation of responsibility and the degree of formalization of the mechanisms used to control actions within the organization. Formal management systems are understood to be the specific process of establishing policies, objectives, plans and programs, budgets and evaluation and reward criteria within the company.

Casillas et al. (2007) consider professionalization in two different aspects. The first element refers to the external or internal character (family or non-family) of the members who hold management positions in family businesses. From the author's point of view, this aspect, despite influencing the company, is not related to the professionalization process. In the second element, professionalization is related to the existence of an organizational and management structure, in which business values prevail and the training and proper training of their managers to the position they hold, belonging to the non-family.

According to the authors Davel and Colbari (2000), and Silva Júnior (2006), the professionalization of companies is a necessary process as the company started familiarly evolves and became more involved in these cases it is needed to adopt a more impersonal management, professional and rational. In this case, if the process of professionalization replaces intuitive methods by rational methods, this organizational movement needs to be 
carried out from the inside out and can have impacts even in the organizational culture (LISSONI et al., 2010).

For Bernhoeft and Gallo (2003), the culture of family business in Brazil is marked by national cultural traits, which in turn have been influenced by cultural characteristics of immigrants. Thus, family enterprises often have their culture based on values such as solidarity, perseverance to overcome adversity and mutual trust among its members, perceived by the symbolic heritage of a common bond. The family reproduces a system of social interaction based on loyalty and submission, which can counteract and prevent movements to the contrary. In this way, individuals, to protect their ties from belonging to the group, sometimes ignore critical awareness, hampering innovation initiatives, which can threaten the continuity of the organization. Thus, these movements directly affect the professionalization process.

Adachi (2006) says that professionalization consists of filling the positions with people who have the skills necessary to fulfill their duties and assume their responsibilities. According to the author, the primary challenge is to identify the skills needed for a given position, since they may be associated with some reasons, such as educational level, professional experience outside the company, or merely being a descendant of the founder. In this way, the author's vision concerns the people who assume some function in the family business.

According to Amendolara (2005), professionalization in the family business is structured from the perspective of power, that is, how the owners of the shareholding control exercise power in the organization and how their relationship with the board of directors and the board of directors works executive.

The professionalization movement does not occur spontaneously. According to Muchon and Campos (1998), the family business has a stimulus to professionalization in periods of crisis and occurring on the side of the so-called "propelling forces".

Professionalization is one of the strongest changes that can happen in a company's life. A firm with typically family management will move faster and easier towards professionalization according to the intensity of a localized crisis on the side of the driving forces (MUCHON; CAMPOS, 1998, p. 28).

For Lodi (1998, p.25), professionalization is the process by which the family or traditional organization assumes more rational, modern and less personalized administrative practices; is the process of integration and of hired and salaried managers among shareholdermanagers; is the adoption of a specific code of training or conduct in a group of workers; is the substitution of intuitive methods for impersonal and rational methods; is the substitution of old or patriarchal forms of hiring labor for salaried and more debatable arrangements.

\subsection{SuCCESION Process}

The process of professionalization of the family business necessarily involves the aspect of succession. For Tondo (2008), succession is the transfer of power in business decisions, knowledge and concludes with the transfer of assets between generations. In the view of Gersick et al. (2006), succession is the supreme test of a family business.

Once it is transformed from individual to family enterprise, its continuity becomes a unique concern. According to Leone (2005), succession is not something that can be resolved overnight. It is a long process that has its foundation, planning and organization. On one hand, the successor must prepare for the position and on the other, what has happened should make this process as clear as possible, telling the family the details of how it is leading the choice.

The succession process represents one of the most important moments in the continuity of the family business. Oliveira (2010) proposes that the analysis of the process of succession in these companies be performed under two types: family succession and 
professional succession. The great importance in family succession is the realistic evaluation that the executive makes about his natural heirs, trying to deceive themselves and affirming that they are the best executives that the company can have in its control. This situation can lead the company to administrative chaos, often irreversibly.

Managerial transmission is a process that begins with the entry of the successor in the company encouraged by the founder. The successor must have sufficient entrepreneurial and managerial skills to ensure the continuity and development of activities within the organization (SHARMA; CHRISMAN; CHUA, 1997). From then on, the successors begin to examine their responsibilities within the company, to enable their participation to lead to succession in the organization (ST-CYR; INOUSSA, 2000).

Patrimonial transmission is commonly understood as a terminal and purely administrative act. However, the quality of the relationship between the founder and the successor causes a high impact on the succession process (ST-CYR; INOUSSA, 2000). Two factors would ensure its success: mutual respect between generations and the adaptation of roles made by the second generation. Ricca (2007) agrees with Oliveira (2010) and says that a correct succession should be planned well in advance and implemented gradually. This process is always risky and can be a very confusing and complicated period in a shareholder's life, both financially and emotionally.

\section{CASE STUDY}

\subsection{CONTEXTUALiZATiON}

For work presentation was agreed with the company that identifying informations would be omitted. In this way, all the names presented are fictitious names.

The story of Company X begins with the Silva family. Mr. Oswaldo and Mrs. Isabel married when they were still in their 20s. They lived in the city of Caxias, Mr. Oswaldo was always an excellent merchant and worked as a representative of a drug company, his wife at the time was an administrative assistant and after the first pregnancy stayed at home taking care of the development of the children, because a year after Victor's arrival was born Renata.

Through the sales activity, Mr. Oswaldo was increasingly negotiation skills, persuasion, and contacts. Over the years, he already had an extensive customer base and knowledge of his customers' purchasing and service processes. And the will to open his own business increased, but he lacked an idea, a direction to start his activities.

It cames at a family dinner when Mrs. Isabel was complaining about the difficulty of hiring a reliable maid who could clean the house. The fulfillment of the scheduled activities and quality standard were the main problems. In addition, Mr. Oswaldo remembered that his clients presented the same difficulty getting professionals for minor house repairs.

At the age of forty-seven, he decided to leave the a seven-years salesman position to invest in his dream. In 1994, with savings and a cliente portfolio, the company X Human Resources Ltda was opened with three employees: Mr. Oswaldo Silva, Jonatas Costa - his longtime friend - and Lourdes Maria, a secretary who wrote down the orders. All fit perfectly in a $35 \mathrm{~m}^{2}$ room in a commercial building on Washington Luiz avenue in Caxias, State of Rio de Janeiro, a low cost and easy access location.

Mr. Oswaldo went out every day to catch new clients in the basin and his friend Jonatas Costa, who had more experience with biddings from city halls, searched all the proclamations to find an opportunity. Mrs. Isabel, despite being a great incentive not to participate in the routine of the new company. His work was related to keeping the family together, as well as maintaining the harmonic relationships in the business. This is because Mr. Oswaldo is a person of impulsive and explosive temperament and his conversations are 
not always balanced and inclusive. When this happened, Mrs. Isabel sought agreements and consensus.

Company $\mathrm{X}$ began its activities offering the service of cleaning in the companies and outsourcing of labor. At first, the first sales occurred in the cleaning area because of the ease of recruiting employees. Understanding that a person should be dedicated to hiring and being responsible for every routine of payroll and labor obligations, the company inserts in its structure a coordinator of Personnel Department. Another position included was Operations Supervisor who should inspect the services ensuring that they were delivered to the client in the traditional time and standard. With the expansion of its services in later years, the company expanded its geographical space, occupying the 5th, 6th, and 7th floors of the same building where the activities started. Figure 5 presents a timeline of the company's evolution.

\begin{tabular}{|c|c|c|c|}
\hline Year & Event & Year & Event \\
\hline 1994 & $\begin{array}{l}\text { Company } X \text { begins its activities offering service of cleaning and conservation and } \\
\text { outsourcing of the work force. }\end{array}$ & 2009 & $\begin{array}{l}\text { With more than ten thousand employees and acting in several Brazilian states, the } \\
\text { company achieves two certifications: ISO14001, OHSAS } 18001 .\end{array}$ \\
\hline 1995 & $\begin{array}{l}\text { Closes new contracts and expands its solutions, starting to offer concierge } \\
\text { services, gardening and reception. }\end{array}$ & 2012 & $\begin{array}{l}\text { Inauguration of the administrative headquarters located in Barra da Tijuca, city of } \\
\text { Rio de Janeiro. }\end{array}$ \\
\hline 1996 & Conquest the first national contract, encompassing operations in five states. & 2013 & Inauguration of the headquarters in Salvador, state of Bahia beginning its \\
\hline 1997 & It reaches 800 employees, $1200 \%$ higher than its foundation year. & & expansion to the northeastern region of Brazil. \\
\hline 1999 a 2002 & Manutenção de crescimento médio anual de $36 \%$, conquistando novos clientes. & 2014 & Inauguration of the Operational headquarters in the center of Rio de Janeiro. \\
\hline 2003 & $\begin{array}{l}\text { The company, already consolidated in the market, employs more than } 3 \text { thousand } \\
\text { employees, having several contracts in public and private companies. }\end{array}$ & 2015 & $\begin{array}{l}\text { Investigation of the company in the Lava Jato investigation scheme carried out by } \\
\text { the federal police of Brazil. }\end{array}$ \\
\hline 2004 & $\begin{array}{l}\text { With } 10 \text { years of experience, it has consolidated its position as a company } \\
\text { specializing in integrated infrastructure solutions. }\end{array}$ & 2016 & $\begin{array}{l}\text { Withholding of the owner and family and sale of the company to another family } \\
\text { business that runs a large estate security company for } 20 \text { years. }\end{array}$ \\
\hline 2005 & $\begin{array}{l}\text { The company achieves ISO } 9001 \text { certification and develops its quality } \\
\text { management program. }\end{array}$ & 2017 & $\begin{array}{l}\text { Change Management line. Son of the new owner, Eduardo takes over the } \\
\text { chairmanship of Company X. }\end{array}$ \\
\hline
\end{tabular}

Figure 5: Company's evolution

Source: author

The company currently has nine thousand employees, an annual turnover estimated at 900 million reais. Changed address, today it is headquartered in the luxury condominium in the city of Rio de Janeiro in the neighborhood of Barra da Tijuca, in addition to an operational headquarters located in the center of Rio de Janeiro. Despite its headquarters in Rio, Company $\mathrm{X}$ has national coverage with branches in São Paulo, Macaé, and Salvador. It has 100 clients distributed by Brazil between the public and private sector. Its portfolio of services has been expanded: cleaning, maintenance, gardening, reception, pest control and waste collection, concierge, toiletry service. To account for the increased complexity of the company departments were set up and directorates established. In figure 6 is the current company structe.

Figure 6: Current organization structure 


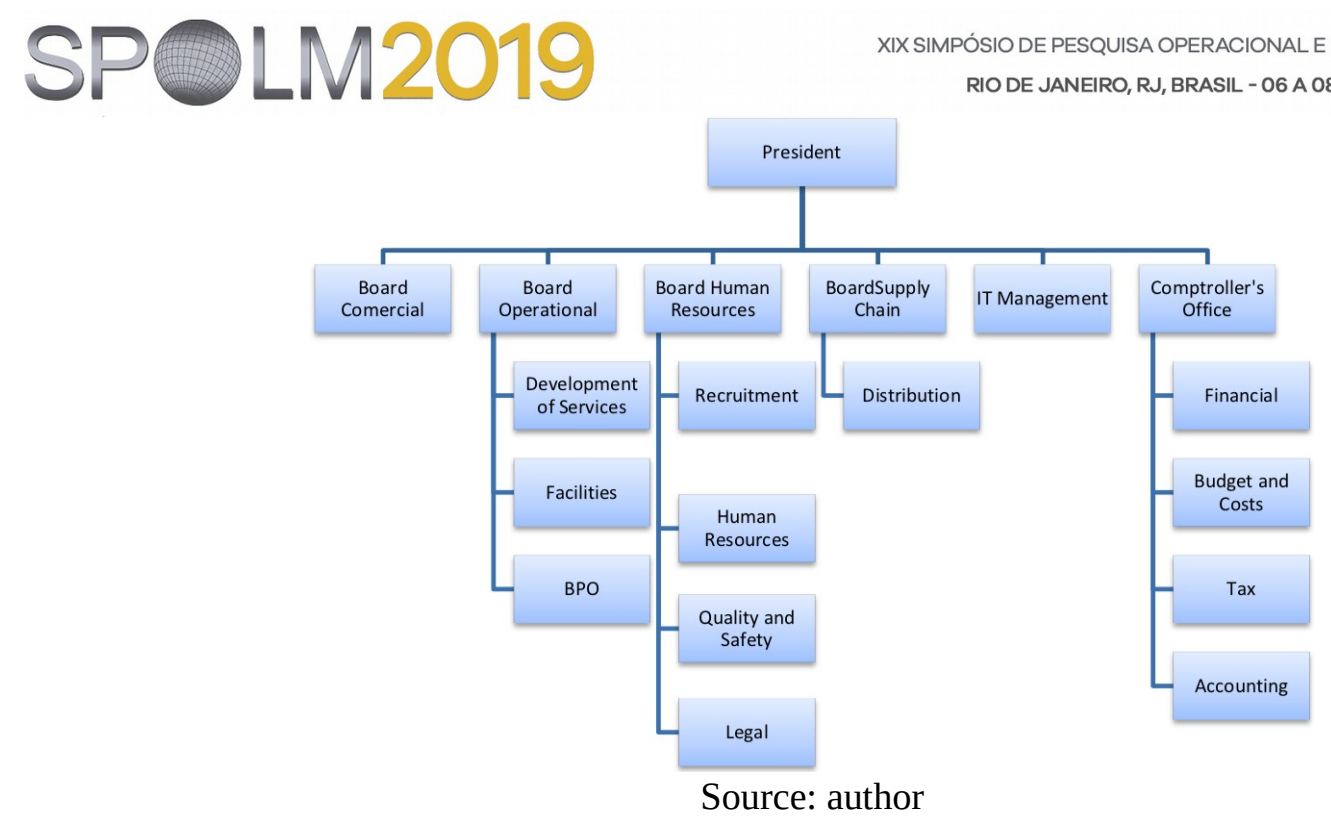

\subsection{Professionalization}

If from the point of people, services, and infrastructure there were major transformations, it was now necessary to structure a plan for the next actions of Company X. At that moment, despite the strong centralization of power in the hands of the founder, $\mathrm{Mr}$. Oswaldo understood that the help of specialists was necessary to assist the company in the development of strategies. And so, it was done, a consulting firm was hired to build strategic planning. In this project, the strategic directors of Company $\mathrm{X}$ were re-negotiated, guiding goals were defined, and goals deployed by the company.

There was no massive involvement of management, the entire process was restricted to the directors of the company and Mr. Oswaldo who accompanied everything with a duality between enthusiasm to see his company grow, and on the other hand was very afraid, because he did not always understand the methodologies that are being used. On this process, he said: "It is an important step for the company. My clients charge me this, and now I'm doing it. But in my opinion those guys come here, smelling, talking pretty, they talk a lot, and they do not say anything. For me, it does not matter if the duck is male, I want to eat the egg. "

In that way, he repeatedly wanted to go back to the old model and continue to give orders as he pleases. It was difficult for him to understand the role of the directors in the organization and the rules that business. This work lasted six months and at the end, the company presented the following parameters:

a) Mission: simplify the clientes operations through a multiservice platform, with efficient, innovative and profitable solutions, respecting life and valuing the team.

b) Vision: to be a reference as the most flexible and modular company in multi-services.

c) Values: agility; customers care; to value the talents and form owners; ghana and discipline; proud; growth with innovation; result commitment result and meritocracy and respect for life.

The Strategic Planning of Company X was elaborated with the Balance Score Card reference, in which objectives and goals are deployed to the managerial level. Regular meetings were established to monitor the strategic plan. These meetings were with $\mathrm{Mr}$. Oswaldo, the directors, and only the operations managers. Corporate managers like human resources, quality, information technology, among others were not invited. This was a discomfort for these managers; they felt distant from Mr. Oswaldo and excluded from the decision making.

They thought it was torturing to attend meetings and Mr. Oswaldo took that responsibility.

It required a relationship with customers and the achievement of a $16 \%$ contribution margin of the contracts. Operations managers were frustrated because there were situations 
where the contract had been sold below the target. In these meetings it was common Mr. Oswaldo to exalt himself with the managers, making them all very insecure and uncomfortable.

The structure of strategic objectives and the actions that have been defined for the company to execute during the period from 2015 to 2018 are shown below in figure 7 .

Figure 7: Strategic objectives and targets from 2015 to 2018

\begin{tabular}{|c|c|c|}
\hline $\begin{array}{l}\text { Goals / Strategic } \\
\text { Objectives }\end{array}$ & General Actions & Target Result / Purpose \\
\hline $\begin{array}{l}\text { 1. Achieve Operational } \\
\text { Excellence }\end{array}$ & $\begin{array}{l}\text { Need for an effective process } \\
\text { structure. }\end{array}$ & $\begin{array}{l}\text { Use as support for the strategy } \\
\text { and certifications that the } \\
\text { company already has. }\end{array}$ \\
\hline $\begin{array}{l}\text { 2. To promote budgetary } \\
\text { austerity }\end{array}$ & $\begin{array}{l}\text { Mapping of all revenues, cost } \\
\text { structure, financing amounts, } \\
\text { loans. }\end{array}$ & $\begin{array}{l}\text { Budgeting is essentially in the } \\
\text { midst of strategic planning and } \\
\text { there is a continuous exercise } \\
\text { of predictability of risks that } \\
\text { could corrupt the austerity of } \\
\text { company accounts. }\end{array}$ \\
\hline 3. Grow Billing with & Use of multiple sales channels & Provide effective and \\
\hline Capillarity and Profitability & and market segments. & $\begin{array}{l}\text { continuous increase of the } \\
\text { company's positive revenues } \\
\text { (inflows). }\end{array}$ \\
\hline $\begin{array}{l}\text { 4. Build an integrated service } \\
\text { platform }\end{array}$ & $\begin{array}{l}\text { Innovate and value with cost } \\
\text { awareness. }\end{array}$ & $\begin{array}{l}\text { Providing concrete and } \\
\text { continuous improvements in the } \\
\text { midst of organizational } \\
\text { processes. }\end{array}$ \\
\hline $\begin{array}{l}\text { 5. Build a talented } \\
\text { organization }\end{array}$ & $\begin{array}{l}\text { Skills compatible with the } \\
\text { challenge, values, mission and } \\
\text { vision of the company, } \\
\text { remunerated by performance } \\
\text { and by meritocracy. }\end{array}$ & $\begin{array}{l}\text { Establishment of a healthy } \\
\text { competitive work environment, } \\
\text { with continuous improvements } \\
\text { not only in the processes, but } \\
\text { also in the employees. }\end{array}$ \\
\hline $\begin{array}{l}\text { 6. Build the brand with solid } \\
\text { foundations }\end{array}$ & $\begin{array}{l}\text { Fulfill the stated promise in the } \\
\text { positioning of organizational } \\
\text { values. }\end{array}$ & $\begin{array}{l}\text { Greater reach of customers and } \\
\text { stratification of the business, } \\
\text { and therefore of the brand, in } \\
\text { the midst of the market space } \\
\text { that it wants to achieve. }\end{array}$ \\
\hline
\end{tabular}

Source: author

\subsection{SUCCESSION}

After twenty-two years under the leadership of its founder, Company $\mathrm{X}$ was preparing to carry out a succession between Mr. Oswaldo Silva and his heir Victor. The plan in a structured way did not exist, was only communicated informally by corridors and meetings.

The preparation of the heir, common in this type of process was treated for years with the insertion still young of the son in the routines of the company. As he ran the activities and experienced the organizational routine, he developed his skills and competencies. The process of succession was long, and there were no disputes between the sons. His son Victor was the only one who was interested in running the company. The main conflict occurred between Mr. Oswaldo and his friend Jonatas. Although Mr. Oswaldo's capital was invested in his totality, over the years and with the growth of the company and his friend as the Vice President, began to demand voice. His loyalty and partnership, according to Jonatas, needed to be recognized. 
Mr. Oswaldo, recognized Jonatas' efforts to help the company grow, and granted a 5\% stake in Company X. From that moment on, Company X now has two: "Silva" and "Souza". The Silva family did not have many family members, they liked to hire new people from the Market and they protected all who remained loyal. The Souza family, on the other hand, was more paternalistic and always sought to hire inbred or "friends of friends."

With all the company's growth and professionalization, the directors hired a consultant to draft a succession plan. The initial proposal was presented and Mr. Oswaldo who was deeply irritated: "Who said I Do I need someone telling me when I should leave? I already told you that Victor is going to take the chair! And the directors stepped back from the project and let the problem as one of the directors said to be resolved in family.

Delaying succession is a feature in the family business as well as conducting the process informally. Victor lived in conflict with the company because he felt that he could assume the position of the father but whenever he tried, he had his authority repressed. It was a complicated process because he, as a diretor, did not feel that he was recognized for his history in the company because he was the owner's son. For this reason, he constantly sought to affirm himself among the others directors.

As Victor's entire experience occurred within Company X's environment, directors worried about the heir's inexperience offered Mr. Oswaldo the alternative of hiring an experienced President who could help his son gain the maturity. The directors wanted $\mathrm{Mr}$. Oswaldo to exercise this movement with a stranger and not directly with the son, and that the son had someone with maturity and other experiences to broaden his vision of the business.

However, before the project of professional succession could be built, in may 2016, they received a visit from the Brazilian Federal Police. Them all were being investigated regarding the payment of bribes for renewal and new contracts with Petrobras.

This action was the 17th carried out as a result of the Lava-Jato Operation scandal. On the visit, documents and computers were taken and a media coverage was held. The company's name was stamped on several vehicles, and some customers rescinded contracts.

Company X had a great dependence on Petrobras, with $60 \%$ of all revenues coming from it. With the second under investigation, payments to suppliers involved in the scheme were suspended, and the contracts were not renewed. Company X, as well as Brazil, has entered into a serious financial, ethical and moral crisis. After several meetings, the Company $\mathrm{X}$ was sold to another family company, Segur SP.

The sale was completed at the end of 2016, closing the history of the Silva e Sousa family in Company X without succession. While this cycle was closed for this family group another cycle of succession was being continued. In 2017, the Almeida family, as well as many executives and professionals from the city of São Paulo begin their activities in Company X.

Segur SP is a market leader in the city of São Paulo with property security services. With the purchase of Company $\mathrm{X}$, it expanded its portfolio of services and increased its national reach. Mr. Joao Almeida, also an entrepreneur, began his activities in 1987. Married to Mrs. Rute, they had two children, respectively: Isabela and Eduardo. Isabela as the eldest daughter took over the company's Social Responsibility Board and Eduardo was prepared since young to take control of the company. He studied in the best American universities and worked in other companies before joining Segur SP.

With the purchase of Company X, Mr. João Almeida saw a possibility to prepare his son Eduardo to take over the group Segur SP. In this way, Eduardo took Company X control, with the challenge to rescue the company out of the crisis.

Assuming Company $\mathrm{X}$ in the process of professionalization Eduardo was benefited by having structured business and processes. It was important because Segur SP does not have 
knowledge or experience in facilities. Meetings were held with Eduardo and the directors to present the business model, customer portfolio, workflows, company organization chart etc. Eduardo's main concern was that the merger generated the smallest possible impact on the company's operation at that time that it remained fragile with numerous sudden changes.

A year later, only the director of human resources remains in the lead. Many managers have been fired or have left the company voluntarily. Managers felt that the financial crisis in Company X was a risky for their careers. Segur SP team, besides the turnover, faced difficulties with the company's culture. As they were also a family business, they had the interest in establishing Segur SP's culture, but it was slow and exhausting.

Eduardo, prevented the company from closing its doors. The monetary crisis is broad, but in its management, the company managed to stop losing customers and sell essential contracts. The synergy between the service portfolios of Company X and Segur SP has not yet been carried out. In the planning, Segur SP expects to sell services of facilities in São Paulo and Rio de Janeiro and other regions of operation of Company X to sell the security services.

Unlike the Silva family, the Almeida family has a succession plan. In, 2025 Eduardo is expected to take control of the group of his father. But for this to happen, it was a definite trajectory for him to gain knowledge and experience.

Eduardo began to participate in the activities of the company as a teenager. His father sought to offer a solid background and forwarded to the American university. He studied business administration, worked for three years in companies outside the family group. The purpose of this, according to Mr. Almeida's belief, was that Eduardo would have security and more Independence to think with his head. He was worried about Eduardo in transcending the family universe and gain the Market and Company $\mathrm{X}$ will be the last challenge.

The path will be great, the group has thirty thousand employees and billing of 1 billion. The purchase of Company $\mathrm{X}$, in the beginning, was a terrific opportunity. When financial books were opened, they found countless situations that will require a lot of resilience, budget discipline and success in recent sales. As every merger process is complicated and vast majority ends up, unsuccessful Eduardo has in his hands the responsibility of reverting to statistics. In addition to the financial situation, the cultural dimension will also require attention.

\section{RESULTS AND FINAL CONSIDERATIONS}

Like many companies in Brazil, Company X was born of family entrepreneurship. Mr. Oswaldo's father wanted to see the company grow and continue from generation to generation, thus perpetuating his name and his courage.

Company $\mathrm{X}$ in the 26 years under the command of the Silva family had exponential growth, with rapid growth adjusted market needs. However, always remaining under the wings of its main client did not identify the risk of this dependence that for many years was the engine of its growth.

In the study, it was possible to identify in Company $\mathrm{X}$ informal management with a strong centralization of power. The founder wanted to participate and exercise all the activities in the company. Even after the growth of the organization, the decision- making power was not delegated, and everything from strategic to procurement, production, sales, hiring, financing, contract with third parties passed its approval.

The misalignment between the organization chart and the company's process structure, absence of defined business rules and standardization of activities were also indicative of a company that had not yet become professionalized, lack of a structure of positions and salaries, the culture of valorization of hiring of friends or family rather than 
professionals; paternalism; reduced possibilities for career advancement, low maturity of financial and budgetary controls add to the diagnosis of informal management.

Company $\mathrm{X}$, under the robust performance of its founder, often found it difficult to separate the family and company, this situation was aggravated by the entry of the Souza family into the shareholder group, leaving employees often without knowing how act in the face of situations. What over the years became a mixture of apathy and conformism, since discussions often carried feelings, emotions from family relationships, and collaborators not being part of the family tended to let members resolve the issue. The organizational renewal was a theme on senior management meetings. However, senior management avoided facing the need to renew its staff, its culture and its systems and, whenever possible, postponed decision-making.

The professionalization movement did not occur spontaneously. Customer pressures acted as a driving force as suggested by Muchon and Campos (1998). The changes promoted in Company X had wave behaviors, advanced and after a brief period, they retreated. It is well known that changing culture is time- consuming and complex. However, when this becomes a characteristic of the company, managers, leaders, and employees do not buy innovative ideas, thus weakening the company's important projects.

In spite of the professionalization project by which the company passed and important advances in certain areas such as Human Resources, Quality and Accounting, in practice Company X was still a disorganized business: strategy not shared by the owner; centralization of decision-making; decisions based on personal aspects and intuition; poorly crafted business reports; repetitive work; hiring without professional criteria; absence in tax and financial planning; absence of risk management and silence on succession.

Often, the directors were communicated only after the decision had been made. Because the founder did not feel secure with the newly created signpost and implanted information systems, he maintained his personal conversations with trusted employees, leaving the organization's strategic planning hampered and the results culture compromised.

This conduct of the founder encouraged the other directors to follow their methods to the detriment of the management model based on metrics. This was maintained if the strategic gap identified by PWC in the survey of Brazilian companies was not increased, that is, Company X's actions were not aligned with the strategic planning developed by the leaders themselves who were now ignoring the established guidelines. As it is known, this situation creates important risks for the sustainability of the business.

About succession, Company $\mathrm{X}$ had been conducting the process for several years. Just as the organizational change that remained on the agenda at meetings, but always postponed, so did the process of succession. The successor Vitor who was being prepared for the hands-on practice had his authority restricted continuously by his father. Vitor had always worked at Company $\mathrm{X}$ and felt prepared, but his father and the directors did not agree. His father because he was reluctant to give up the position and the directors because they believed that before the size of the company it was important that Company $\mathrm{X}$ first went through a process of change of control through the experienced president, during that period Vitor would accompany and receive a mentoring. Faced with the clashes of interests reaching a common denominator was difficult and little was known about succession.

With the late professionalization, succession in the debate, and mainly crisis established by the Lava-Jato operation, the Silva Family succumbed, there was no other alternative than the sale and withdrawal of the family from the business that it had built before. Silva family increases the group of $70 \%$ of companies that do not go to the second generation.

With the late professionalization generated the following question: Could it be 
professionalization of the company to prevent such events? The problems that Company $\mathrm{X}$ faced and lost were related to compliance, such as payment of bribes, agreement on the results of bids, favoritism of third parties, etc. and this does not directly concern professionalization or succession. However, if the company had professionalized earlier it could have matured to recognize the risks of its business, it could have looked for diversification of its client portfolio to reduce the dependency of the public sector. These actions could, if not avoid, at least create a more solid structure for Company $\mathrm{X}$ to support itself in times of crisis.

The fact is that when looking to analyze how the professionalization and succession process occurs in a family business, it was possible to recognize that professionalization should not be treated as an isolated project. It requires a program to promote this culture, or it will be done only in a bureaucratic and non- transformational way.

Regarding succession, Company $\mathrm{X}$ missed the opportunity to have it structured, as many authors suggested. With the abrupt departure of the company, Silva's legacy was continued by the hands of the Almeida family. And differently, they followed experts recommendations in the succession process and done it better. The challenge now is to rescue Company $\mathrm{X}$ reducing the risk to the Segur SP group and make sure that Eduardo is ready to take his father's control. Besides his preparation was diferente, he has, unlike Victor, the support of his father. Mr. Almeida has clarity of its finitude and seeks in the son the continuity of the family's dream. Mr. Oswaldo also had the same desire, but behind him, there was an intense desire to continue alone receiving in a somewhat egoic form the laurels of his courage.

This work is finished by highlighting the complexity of the human factor and how their relationships profoundly impact organizations. Gersick et al. (2006) identified the separation of family, property, and management recognizing the difficulty of human relationships. Although there are numerous tools, numerous systems, the most varied management models available the maximum persists, "an organization is made up of people," whether in a family business or a non-family business. So if people do not get worked up to project design, it's difficult for organizations to achieve longevity and profitability.

\subsection{FUTURE WORKS}

As a suggestion, future investigations may extend the studies in family companies regarding gender in the subject of succession. This work was based on a case study where two successor companies had as successor the son while the wives and daughters were acting behind the scenes. Also, it would be valid to investigate if there is a cultural reproduction of the Brazilian society, where whites are managers and where historically are excluded: blacks, poor, women, suburban residents with little chance of ascension in the organization.

\section{REFERENCES}

\section{BIBLIOGRAPHIC REFERENCES}

[1] ADACHI, P. P. Família S.A.: Gestão de Empresa Familiar e Solução de Conflitos. São Paulo: Atlas, 2006.

[2] ÁLVARES, E. Governando a empresa familiar. Rio de Janeiro: Qualitymark, 2003.

[3] AMENDOLARA, L. A sucessão na empresa familiar. São Paulo: Lazuli, 2005.

[4] BERNHOEFT, R.; GALLO, M. A. Governança na Empresa Familiar: gestão, poder e sucessão. Rio de Janeiro: Elsevier, 2003.

[5] BORGES, A. F.; LESCUTA, C. Sucessão em empresas familiares: um olhar sobrea a pesquisa brasileira. In: Encontro da Associação Nacional de Pós-graduação e Pesquisa em Administração. v.36. Anais.Rio de Janeiro: ANPAD, 2012. 
[6] CANÇADO, V. L. et al. Ciclo evolutivo e sucessão em uma empresa familiar: um estudo de cado no grupo Seculus. In: Encontro da Associação Nacional de Pós-graduação e Pesquisa em Administração. v.35. Anais. Rio de Janeiro. ANPAD, 2011.

[7] CASILLAS, José Carlos; VÁZQUEZ, Adolfo; DIAZ, Carmen. Gestão da empresa familiar: conceitos, casos e soluções. São Paulo: Thomson Learning, 2007.

[8] CERIBELI, H. B.; MERLO, E. M.; MORAIS, F. S. Análise do processo de profissionalização da gestão de empresas familiares atuantes no varejo. Revista Eletrônica de Ciência Administrativa. Faculdade Cenecista de Campo, 2010.

[9] DAVEL, E.; SILVA, J.C.S.; FISCHER, T. Desenvolvimento tridimensional das organizações familiares: avanços e desafios teóricos a partir de um estudo de caso. Salvador: Organização \& Sociedade, v. 7, n. 18, p. 99-116, maio/ago. 2000.

[10] DAVEL, Eduardo; COLBARI, Antônia. Organizações familiares: por uma Introdução a sua Tradição, contemporaneidade e multidisciplinaridade. v. 7, n.18, 2000.

[11] ELSEN, I. Cuidado familial: uma proposta inicial de sistematização conceitual. In: ELSEN, I; MARCON, S. S.; SANTOS, M. R. dos (Orgs.). O viver em família e a sua interface com a saúde e a doença. Maringá: Eduem, 2002.

[12] GAJ, Luis. Tornando a Administração Estratégica Possível. São Paulo: McGraw-Hill, 1990.

[13] GALLO, M. A. La sucessión em la empresa familiar. Bercelona. La Caixa, 2003.

[14] GERSICK, K.E., DAVIS, J.A.; HAMPTON, M. M. C.; LANSBERG, I. Generation to Generation: Life Cycles of the Family Business. Boston: Harvard Business School Press, 2006.

[15] GONÇALVEZ, Sérgio de Castro. As Empresas Familiares no Brasil. Revista de Administração de Empresas, RAE Light. São Paulo, v.7, n.1, p. 7-12, Jan/Mar. 2000.

[16] LANZANA, A ., CONSTANZI, R. As empresas familiares brasileiras diante do atual panorama econômico mundial. São Paulo: Negócio Editora, 1999.

[17] LEONE, Nilda Maria de Clodoaldo Pinto Guerra. Sucessão na empresa familiar: preparando as mudanças para garantir sobrevivência no mercado globalizado. São Paulo: Atlas, 2005.

[18] LODI, J. B. A empresa familiar. 4ed. São Paulo: Pioneira, 1998.

[19] MARTINS, Ives; MENEZES, Paulo; BERNHOEFT, Renato. Empresas familiares brasileiras: perfil e perspectivas. São Paulo: Negócio, 2012.

[20] MUCHON, Domingos; CAMPOS, Elismar Álvares da Silva. A profissionalização da empresa familiar. Ensaio. Belo Horizonte: Fundação Dom Cabral, 1998.

[21] OLIVEIRA Djalma de Pinto Rebouças. Planejamento estratégico conceitos metodologia e práticas. 19 ed. São Paulo: Atlas, 2010.

[22] PADULA, A. D. A empresa familiar: fases de crescimento e de desenvolvimento gerencial. Passo Fundo: UPF, 2002.

[23] PAPA, Adriana Cássia. O papel do fundador na cultura de uma empresa familiar. Dissertação (Mestrado). Faculdade Novos Horizontes. Belo Horizonte, 2007.

[24] RICCA, Domingos. Sucessão na empresa familiar: conflitos e soluções. São Paulo: CLA, 2007.

[25] SHARMA, P.; CHRISMAN, J.J.; CHUA, J.H. Strategic management of the family business: past research and future challenges. Family Business Review, v.10, n.1, p.1-35, 1997.

[26] SILVA JÚNIOR, Annor da. Trajetória de crescimento, governança corporativa e gestão universitária: estudo de caso em três instituições de educação superior do tipo familiar. Belo Horizonte: UFMG, 2006, 383 p. Tese (Doutorado). Belo Horizonte, 2006.

[27] ST-CYR, L.; INOUSSA, R. La planification de la relève dans la PME: revue de la littérature et aveneues de recherche. In: Congrès International Francophone Sur La PME, 2000.

[28] TONDO, C. Desenvolvendo a empresa familiar e a família empresária. Porto Alegre: Sulina, 2008.

[29] WERNER, René A. Família \& Negócios: um caminho para o sucesso. Barueri, SP: Manole, 2004. 


\section{ELETRONIC REFERENCES}

[30] SEBRAE. Sobrevivência das empresas no Brasil. 2016. Available at: <http://www.sebrae.com.br/Sebrae/ Portal\%20Sebrae/Anexos/sobrevivencia-das-empresas-no-brasil-relatorio-2016.pdf >. Accessed in 18 aug. 2018.

[31] ULRICH, Steffen. Decifrando o mistério da empresa familiar - uma perspectiva etnológica. Rede CEFE International. 1997. Available at: < http:// cefe.gtz.de/ português/products/brainsto/4- 97-1.htm>. Accessed in 17 aug. 2018. 